\title{
Standarization of fresh elephant foot yam based value added products
}

\author{
ANJALI YADAV AND SADHNA SINGH
}

Received: 17.06.2017; Revised: 22.10.2017; Accepted: 07.11.2017

See end of the paper for authors' affiliations

\section{ANJALI YADAV}

Department of Foods Science and

Nutrition, N.D. University of

Agriculture and Technology, Kumarganj, FAIZABAD (U.P.) INDIA
ABSTRACT : The present study was done to assess the organoleptic acceptability, nutritional composition and economics of value added products developed from corms of released variety elephant foot yam (NDA-9). Among various value added products the highest sensory mean score was obtained by veg rolls (9.0) followed by bread roll (8.98), momos (8.88), chokha (8.86), tikki (8.38), suran pakodi (8.38), suran paratha (8.00), and suran sabji (7.54). Nutritionally Veg roll contained the highest protein value $(4.88 \mathrm{~g} / 100 \mathrm{~g})$, suran ki pakodi contained highest calcium value $(62.40 / 100 \mathrm{~g})$ and tikki had highest iron content $(4.11 \mathrm{mg} / 100 \mathrm{~g})$ among all the products and economically veg roll and momos (Rs. 3.50/100g) were least expensive as compared to other products and suran pakodi was the most expensive (Rs. 12.86/100g).

KEY WORDS: Elephant foot yam, Value addition, Organoleptic properties, Nutritional composition, Economics

- HOW TO CITE THIS PAPER : Yadav, Anjali and Singh, Sadhna (2017). Standarization of fresh elephant foot yam based value added products. Asian J. Home Sci., 12 (2) : 540-544, DOI: 10.15740/HAS/AJHS/ 12.2/540-544. 